\title{
An Empirical Analysis of Directors' Performance, Remuneration and Corporate Performance of Chinese Listed Companies
}

\author{
Jun Zhou, Ruoxue Bu \\ School of Economics, Wuhan University of Technology, Wuhan, China \\ Email: zhoujun601@sina.com
}

How to cite this paper: Zhou, J., \& Bu, R. X. (2020). An Empirical Analysis of Directors' Performance, Remuneration and Corporate Performance of Chinese Listed Companies. iBusiness, 12, 127-139. https://doi.org/10.4236/ib.2020.124009

Received: November 9, 2020

Accepted: December 4, 2020

Published: December 7, 2020

Copyright (๑) 2020 by author(s) and Scientific Research Publishing Inc. This work is licensed under the Creative Commons Attribution International License (CC BY 4.0).

http://creativecommons.org/licenses/by/4.0/

\section{(c) (i) Open Access}

\begin{abstract}
In listed companies, directors (including independent directors and non-independent directors, etc.) are responsible for grasping the company's development direction, deciding on major company matters, and supervising the management, so as to obtain certain remuneration from the company. Therefore, directors' performance and remuneration in return for their performance will inevitably affect the corporate governance level of listed companies and thus affect performance of listed companies. This article takes the performance of directors of listed companies and the remuneration of directors as the entry point. From the perspectives of rights and obligations, this paper studies the relationship between the performance of directors, remuneration and company performance, in order to improve the governance level of directors of listed companies. Based on the data of Shenzhen and Shanghai A-share listed companies from 2005 to 2019, this paper analyzes the relationship between directors' performance, remuneration and company performance of Chinese listed companies. The results show that directors' meeting attendance is positively correlated with company performance; and there is no obvious correlation between directors' negative opinions and company performance; directors' remuneration is significantly positively correlated with company performance. The research in this article has positive enlightenment and reference for improving the directors' governance of listed companies. Finally, based on the conclusions, several countermeasures and suggestions are proposed to improve the governance of directors: further clarify the responsibilities of directors to avoid confusion and overlap with management responsibilities; give full play to the supervisory function of directors to management, especially pay attention to the supervisory duties of non-independent directors or internal directors; the remuneration of directors should be more reasonable, and the remuneration should be determined
\end{abstract}


according to the requirements and performance of directors' duties; improve the evaluation and assessment mechanism of directors, pay more attention to the qualifications and ability of directors.

\section{Keywords}

Directors' Performance, Directors' Responsibility, Directors' Remuneration, Corporate Performance

\section{Introduction}

Directors, that are members of the board of directors, are senior managers who act for shareholders to supervise or control company affairs. Historically, the duties of directors have undergone a process of development and evolution. Before the 1870s and 1880s, in the early joint-stock companies, directors were those who represented shareholders to manage and supervise the operation of the company. The special decree passed by the British Parliament in 1844 clearly stated that the director is the person who directs, handles and supervises the affairs of the company. After this until the Second World War, in the United Kingdom and the United States and other countries, the board of directors generally had a dual function, that is, on the one hand to engage in business management, on the other hand to bear the responsibility of supervising senior managers. Correspondingly, directors have a dual role, management and supervision. After the Second World War, the management function of the board of directors gradually faded and became a leading and supervisory agency. Especially after the 1960s, with the establishment of the CEO system, the company's operation and management affairs are in charge of the management team headed by the CEO, and the board of directors mainly leads the company and supervises the CEO and its management team (Machold \& Farquhar, 2013). Since the 1990s, the legislation of various countries has also abandoned the position of the board of directors as a universal organ, and the laws have positioned it as the controlling organ to lead and supervise the company (Zhang, 2007). In this case, the role of directors has also changed, and they have mainly become leaders and supervisors rather than managers. In different countries, directors are divided into independent directors and non-independent directors, executive directors and non-executive directors, internal directors and external directors, but no matter what type of directors, they are responsible for leading the company and supervising the management. Trick (1997) believes that all directors have the same responsibilities, no matter whether they are executive directors or non-executive directors. No matter whether it is an individual director or a group of directors, it is the responsibility to ensure that the company is properly managed, abides by laws and regulations, and is in the interests of shareholders. Jonathan Chakham (2006) also pointed out that the "Company Law" does not require directors to become managers, but only requires directors to understand whether the com- 
pany's management is appropriate. In his view, legally speaking, there is only one type of director. And all directors are equal. Both "non-executive directors" and "executive directors" have the responsibility of supervising the management.

In the operation and management of listed companies, there is a very common problem: people often emphasize the supervisory function of independent directors over the management too much, while neglecting the supervisory function of directors as a whole. Most laws believe that directors have two responsibilities in managing company affairs and performing company business, namely, loyalty and care. Therefore, in essence, whether they are independent directors or non-independent directors, internal directors or outside directors, executive directors or non-executive directors, they are all actors that supervise and constrain the management, and they all need to perform their duties to the management. And this is precisely the point ignored by listed companies.

The research of this article mainly starts from the following six aspects. The first part introduces the background of the article research; the second part reviews the relevant literature; the third part puts forward relevant hypotheses based on theoretical analysis; the fourth part designs the empirical research; the fifth part reports the regression results; the sixth part draws the conclusion of the article based on the analysis of the full text, and gives relevant suggestions.

\section{Literature Review}

\subsection{Directors' Performance and Company Performance}

Jonathan Chakham (2006) believed that in developed countries such as Britain, France and the United States, directors generally do not perform their duties effectively, so that the board of directors cannot effectively supervise and restrain the management. Zhang and Ling (2010) believed that independent directors who have both theoretical knowledge and rich practical experience can effectively perform their duties and play a very important role in the development of the company. Ye, Zhu and $\mathrm{Lu}$ (2011) believed that the market value of companies is higher when the independent directors' put forward negative opinions on board meeting proposals. Pugliese, Nicholson, and Bezemer (2015) believed that the interaction between directors can improve the efficiency of the board of directors, thereby improving company performance. Wang and Bao (2014) believed that the average attendance rate of independent directors is positively related to company performance. Zhou, Luo, and Zhang (2016) believed that increasing the number of independent directors participating in meetings will help improve supervision efficiency and improve company performance. Jiang et al. (2016) believed that directors questioned the company's proposals and actively performed their supervisory functions, which can improve corporate governance and thereby enhance company performance. Zhou, Wang, and Zhang (2018) studied the relationship between the effectiveness of independent directors' performance of duties and company performance. They believed that the information provided by the secretary of the board of directors can promote the effec- 
tiveness of independent directors' performance of duties, and that the effectiveness of independent directors' performance of duties can improve the company performance. Sun (2019) used independent directors' performance as a moderator to study the impact of corporate governance on company performance, and believed that independent directors' performance has a positive effect on the impact of corporate governance on company performance.

\subsection{Directors' Remuneration and Company Performance}

There are two views of "irrelevant" and "relevant" on this issue. First look at "irrelevance theory". Yang and Gao (2009) believed that there is a widespread lack of director incentives in Chinese listed companies, and directors' remuneration has no significant impact on company performance. Zhou, Zhou, Qu, and Sun (2010) believed that there is no correlation between directors' remuneration and company performance. Wu and Lan (2009) believed that the remuneration of independent directors is not related to company performance. Second, look at the "relevance theory". Han (2015) believed that directors' remuneration has a significant positive impact on company performance. Regarding the relationship between independent directors' remuneration and company performance, academia has done a lot of research, and most of them believe that there is a positive correlation between independent directors' remuneration and company performance. For example, Li \& Sun (2007), Gao, Luo and Zhang (2007), Lin \& Jin (2009), Zhang (2014), and Li (2017) all believed that there is a positive correlation between independent directors' remuneration and company performance.

It can be seen that the academia has done a lot of research on related issues, but these studies are mainly carried out from the perspective of independent directors, and cannot be equated to the analysis of the group of directors. The research on the responsibilities, remuneration, and functions of independent directors cannot replace the analysis on the responsibilities, remuneration, and functions of director groups including independent directors and non-independent directors. In fact, in director governance, non-independent directors also play an important role in leading the company and supervising the management, and this role has not been fully revealed in the existing research. Compared with the current research, the main contribution of this article is to examine directors (including independent directors and non-independent directors) as a group, analyze the relationship between directors' performance, remuneration and company performance, and reveal the directors' role in corporate governance.

\section{Theoretical Analysis and Research Hypothesis}

Directors perform their duties, such as deciding the company's major policies and major issues, and supervising management, they are basically carried out through the directors' participation in board meetings. Therefore, the number of directors' participation in meetings can be used to evaluate the performance of directors indirectly. Generally speaking, the attendance rate of directors can re- 
flect their work status and effort. In theory, the more directors attend board meetings, the higher their attendance rate will be, their leadership and supervisory functions will be better, and the company's performance will be better.

The proposals that were reviewed and decided at the board meetings involved major issues such as the company's developing plan, investment plan, budget and final accounts plan, profit distribution, the establishment of management institutions, and the appointment and removal of important personnel. At the board meeting, the directors shall express their opinions and vote on the proposals of the board meeting. Board meeting proposals are generally proposed by the management or management department. When the management or management department is drafting and proposing board meeting proposals, they often consider short-term gains and losses or their own interests. Therefore, directors put forward negative opinions on board meeting proposals (negative opinions include reservations, opposing views and objections, same below), which means that it can effectively perform its supervisory duties to the management, thereby improving company performance.

Generally speaking, if the director's remuneration is too low, it will affect the enthusiasm of the directors, making them unwilling to supervise the management effectively, thereby reducing the company's performance. If the director's remuneration is too high, it will affect their independence, and making directors unable to effectively supervise the management, thereby reducing company performance. Therefore, the setting of directors' remuneration must be reasonably. Within a range of remuneration, the higher the director's remuneration, the greater the incentive he receives. Under the higher remuneration incentive, the directors will actively perform its supervisory function, thereby improving company performance.

Accordingly, this article puts forward:

Hypothesis 1: The higher the director's meeting attendance, the better the company's performance.

Hypothesis 2: When the directors put forward negative opinions on the board meeting, the company's performance will be better.

Hypothesis 3: Directors' remuneration has a positive impact on company performance.

This article mainly uses the coefficients of various variables in the regression model (directors' meeting attendance, whether the directors have negative opinions on the board meeting proposals, and directors' remuneration) to verify the above three hypotheses. If the coefficient is significant, the hypothesis is verified, otherwise, the hypothesis is invalid.

\section{Research Design}

\subsection{Sample Source and Selection}

This paper selects the data of Shenzhen and Shanghai A-share listed companies from 2005 to 2019 for research. The data mainly comes from the CSMAR data- 
base, supplemented by the annual reports of listed companies disclosed by the Shanghai Stock Exchange and Shenzhen Stock Exchange. The measurement software used is mainly Stata 14 .

In order to ensure the validity of the data, the data is screened and processed according to the following steps: 1) Eliminate financial and insurance listed companies; 2) Eliminate listed companies processed by ST; 3) Eliminate missing data and outliers; 4) According to the annual report of the listed company, supplement the information on the number of directors' participation in board meetings, and manually check the director's remuneration information. Finally, 3624 qualified valid sample data, 32,899 company-year observations, and 195,272 company-year-director observations were obtained.

\subsection{Variable Selection and Definition}

This article examines the relationship between directors' performance, remuneration and company performance. The return on total assets is used to reflect the performance of the company, the attendance rate of directors and whether they have issued a negative opinion on the board meeting is used to reflect the performance of the directors, and the natural logarithm of the director's personal remuneration is used to reflect the level of compensation. The control variables are company governance level, company size, debt level and fixed asset ratio (see Table 1). At the same time, this article also controls the dummy variables of industry and year. Considering that the two variables (Salary and Size) are quite different internally, in order to make the data relatively stable and eliminate the influence of heteroscedasticity, this paper takes the logarithm of these two variables.

\subsection{Measurement of Company Governance}

There are many variables to measure the governance level of listed companies, and they are generally related. Putting these variables together to do regression will cause serious multicollinearity. Therefore, this article selects 13 variables from the internal governance and external governance levels (see Table 2) to

Table 1. Definition of main variables.

\begin{tabular}{|c|c|}
\hline Variables name & Variables definitions \\
\hline $\mathrm{ROA}$ & (Total profit plus financial expenses) divided by total average assets \\
\hline Attend & $\begin{array}{l}\text { Number of directors attending board meetings in person divided by number of } \\
\text { board meetings }\end{array}$ \\
\hline Opinion & The negative opinion of the directors on the board meeting is 1 , otherwise it is 0 \\
\hline Salary & Natural logarithm of director's personal remuneration \\
\hline G & Comprehensive governance level of listed companies \\
\hline Size & Natural logarithm of listed company's total assets \\
\hline Debt & Total liabilities divided by total assets \\
\hline Fixed & Net fixed assets divided by total assets \\
\hline
\end{tabular}


Table 2. Corporate governance indicators.

\begin{tabular}{|c|c|}
\hline Variable name & Variable definition \\
\hline Meeting & Number of board meetings held annually \\
\hline Board & Number of Board of Directors \\
\hline Board shareholding ratio & $\begin{array}{l}\text { Number of company shares held by the board of directors } \\
\text { divided by total number of company shares }\end{array}$ \\
\hline Proportion of independent directors & $\begin{array}{l}\text { Number of independent directors divided by total number } \\
\text { of directors }\end{array}$ \\
\hline $\mathrm{CEO}$ & $\begin{array}{l}\text { The combination of chairman and general manager is } 1 \text {, } \\
\text { otherwise } 0\end{array}$ \\
\hline Number of special committees & Number of committees under the board of directors \\
\hline Executive compensation & $\begin{array}{l}\text { The natural logarithm of the total remuneration of the top } \\
\text { three executives }\end{array}$ \\
\hline Share & Proportion of the largest shareholder \\
\hline $\mathrm{Z}$ index & $\begin{array}{l}\text { Proportion of the largest shareholder divided by proportion } \\
\text { of the second largest shareholder }\end{array}$ \\
\hline Cstr2_10 & $\begin{array}{l}\text { Sum of the square of the second to tenth largest } \\
\text { shareholder's shareholding ratio }\end{array}$ \\
\hline State holding & State-owned holding is 0 , otherwise 1 \\
\hline Parent & Has a parent company of 0 , otherwise 1 \\
\hline Market & Listed in other markets is 1 , otherwise 0 \\
\hline
\end{tabular}

study the level of company governance, using principal component analysis to construct a $\mathrm{G}$ index to reflect the comprehensive governance level of listed companies.

\subsection{Research Methods and Model Design}

This article mainly adopts empirical analysis method to study the influence of directors' performance and remuneration on company performance. Based on the data of Shenzhen and Shanghai A-share listed companies from 2005 to 2019, this paper conducts an empirical analysis of the influence of directors' performance and remuneration on company performance in China's listed companies, trying to illustrate the role of directors as a group in company governance.

Taking into account the influence of the year and industry on the model estimation, this paper controls the year and industry and establishes the following regression model (where $i$ represents the company, $j$ represents the director, and $t$ represents the year):

$$
\begin{aligned}
\mathrm{ROA}_{i j t}= & a_{0}+a_{1} \text { Attend }_{i j t}+a_{2} \text { Opinion }_{i j t}+a_{3} \text { Salary }_{i j t} \\
& +a_{4} \mathrm{G}_{i j t}+a_{5} \text { Size }_{i j t}+a_{6} \operatorname{Debt}_{i j t}+a_{7} \text { Fixed }_{i j t}+\varepsilon
\end{aligned}
$$

\section{Empirical Results and Analysis}

\subsection{Descriptive Statistics}

It can be seen that the average return on total assets of listed companies in China 
is 0.008 , the median is 0.007 , the minimum is -16.669 , and the maximum is 4.412. There is a big difference. This is closely related with company size, debt level, fixed asset ratio and company governance status. The average attendance rate of directors at meetings is 0.895 , the median is 1 , the maximum is 1 , and the minimum is 0 , indicating that the directors of listed companies are still relatively active in participating in board meetings. The average value of whether or not directors put forward negative opinions on board meeting proposals is 0.006 , indicating that directors of listed companies are not happy to give negative opinions on board meeting proposals, and 6 out of every 1000 directors may give negative opinions. The average director's remuneration is 6.494 , the median is 10.309 (about 30,000 yuan), the minimum is 0 , and the maximum is 15.425 (about 5,000,000 yuan). The difference is large (see Table 3 ).

\subsection{Correlation Analysis}

Correlation test show that company performance is positively correlated with directors' meeting attendance rate, and is significant at the level of $0.1 \%$. Company performance is positively correlated with directors' remuneration, which is significant at $1 \%$ level. Whether the directors put forward negative opinions on the board meeting has no obvious correlation with company performance, this is due to the coefficient of Opinion is not significant (see Table 4).

Table 3. Descriptive statistics.

\begin{tabular}{ccccccc}
\hline Variable name Number of samples & Average & \multicolumn{2}{c}{ Median } & Standard deviation & Minimum & Maximum \\
\hline ROA & 195,003 & 0.008 & 0.007 & 0.100 & -16.669 & 4.412 \\
Attend & 195,272 & 0.895 & 1.000 & 0.219 & 0.000 & 1.000 \\
Opinion & 195,272 & 0.006 & 0.000 & 0.075 & 0.000 & 1.000 \\
Salary & 195,272 & 6.494 & 10.309 & 5.347 & 0.000 & 15.425 \\
G & 194,394 & -0.000 & -0.024 & 0.341 & -2.498 & 1.455 \\
Size & 195,254 & 22.083 & 21.910 & 1.428 & 10.842 & 28.636 \\
Debt & 195,254 & 0.521 & 0.454 & 4.716 & -0.195 & 877.256 \\
Fixed & 195,254 & 0.243 & 0.204 & 0.183 & 0.000 & 0.971 \\
\hline
\end{tabular}

Table 4. Person correlation coefficient table.

\begin{tabular}{|c|c|c|c|c|c|c|c|c|}
\hline & $\mathrm{ROA}$ & Attend & Opinion & Salary & G & Size & Debt & Fixed \\
\hline $\mathrm{ROA}$ & 1.000 & & & & & & & \\
\hline Attend & $0.012^{\star * *}$ & 1.000 & & & & & & \\
\hline Opinion & -0.000 & -0.003 & 1.000 & & & & & \\
\hline Salary & $0.007^{\star *}$ & $-0.111^{\star \star *}$ & $0.055^{\star * *}$ & 1.000 & & & & \\
\hline G & $0.046^{* * *}$ & $-0.031^{\star * *}$ & $-0.034^{* * *}$ & $0.155^{* * *}$ & 1.000 & & & \\
\hline Size & $0.066^{\star * *}$ & $0.010^{* * *}$ & $-0.034^{* * *}$ & $-0.032^{\star * *}$ & $0.080^{\star * *}$ & 1.000 & & \\
\hline Debt & $-0.901^{\star * *}$ & $-0.010^{\star * *}$ & $0.006^{\star *}$ & -0.004 & $-0.045^{\star * *}$ & $-0.056^{* * *}$ & 1.000 & \\
\hline Fixed & 0.002 & $0.011^{* * *}$ & $0.014^{\star * \star}$ & $-0.062^{\star \star \star}$ & $-0.244^{\star * \star}$ & $0.109^{\star * *}$ & -0.004 & 1.000 \\
\hline
\end{tabular}

Note: ${ }^{*}$ means significant at the $5 \%$ level, ${ }^{*}$ means significant at the $1 \%$ level, and ${ }^{* *}$ means significant at the $0.1 \%$ level. 


\subsection{Regression Analysis}

The regression showed that the regression equation passed the $\mathrm{F}$ test at a significance level of $0.1 \%$, and the model goodness of fit reached $81.34 \%$, indicating that the model has strong explanatory power (see Table 5). Attend's coefficient is significantly positive at the $0.1 \%$ level, indicating that the director's meeting attendance is positively correlated with company performance, that is, the higher the director's meeting attendance, the better the company's performance. The coefficient of Opinion is not significant, indicating that whether the directors put forward negative opinions on the board meeting has no obvious correlation with company performance. Salary's coefficient is significantly positive at the level of $5 \%$, indicating that directors' remuneration is positively related to company performance, that is, the higher the director's remuneration, the better the company's performance.

\subsection{Robustness Test}

\subsubsection{Endogenous Problems}

Considering that there is a reverse causal relationship between directors' performance and directors' compensation, there may be endogenous problems in the model. This article uses the number of annual board meetings as an instrumental variable for the attendance rate of the board meeting. Whether the directors put forward negative opinions on the board meeting for a period of time is used as an instrumental variable for whether the directors put forward negative opinions on the board meeting. And the company's industry is used as an instrumental variable for directors' remuneration. The model is re-estimated using the GMM method. Through analysis, it is found that after controlling endogeneity, the conclusion of this paper is still robust (see Table 6).

Table 5. The impact of directors' performance and remuneration on company performance.

\begin{tabular}{cccc}
\hline Explained variable: ROA & Coefficient & $t$ value & $P$ value \\
\hline Attend & $0.001^{* * *}$ & 3.62 & 0.000 \\
Opinion & 0.003 & 1.11 & 0.268 \\
Salary & $0.000^{*}$ & 2.43 & 0.015 \\
G & $0.005^{* * *}$ & 13.82 & 0.000 \\
Size & $0.002^{* * *}$ & 5.41 & 0.000 \\
Debt & $-0.020^{* * *}$ & -44.80 & 0.000 \\
Fixed & $-0.005^{* * *}$ & -11.04 & 0.000 \\
constant & $-0.019^{* * *}$ & -2.84 & 0.005 \\
Industry & & Control & \\
Year & & Control & \\
$\mathrm{R}^{2}$ & & 0.8134 & \\
F & & 3582.33 & \\
\hline
\end{tabular}

Note: ${ }^{*}{ }^{* *},{ }^{* *}$ mean significant at the level of $10 \%, 5 \%$, and $1 \%$. The $t$ value under the robust standard error of heteroscedasticity. 
Table 6. The influence of directors' performance and remuneration on company performance (control endogenousness).

\begin{tabular}{cccc}
\hline \multicolumn{4}{c}{ Explained variable: ROA } \\
\hline Instrumental variable & Meeting & L.Opinion & Industry \\
\hline Attend & $0.070^{* *}(11.71)$ & $0.002^{* * *}(4.00)$ & $0.075^{* * *}(4.41)$ \\
Opinion & $0.003(0.91)$ & $0.084(1.55)$ & $-1.112^{* * *}(-4.18)$ \\
Salary & $0.000^{* * *}(9.76)$ & $-0.000(-1.11)$ & $0.028^{* * *}(4.36)$ \\
G & $0.005^{* *}(14.04)$ & $0.005^{* * *}(11.35)$ & $-0.067^{* * *}(-4.05)$ \\
Size & $0.002^{* * *}(5.11)$ & $0.002^{* * *}(6.07)$ & $0.005^{* * *}(5.20)$ \\
Debt & $-0.019^{* * *}(-44.97)$ & $-0.018^{* * *}(-13.65)$ & $-0.019^{* * *}(-44.56)$ \\
Fixed & $-0.005^{*}(-9.96)$ & $-0.006^{* * *}(-12.11)$ & $0.015^{* * *}(3.31)$ \\
constant & $-0.081^{* * *}(-7.24)$ & $-0.030^{* * *}(-4.91)$ & $-0.367^{* * *}(-4.42)$ \\
Industry & Control & Control & Not control \\
Year & Control & Control & Control \\
$\mathrm{R}^{2}$ & 0.7910 & 0.6104 & -- \\
\hline
\end{tabular}

Note: ${ }^{*}{ }^{* *},{ }^{* *}$ mean significant at the level of $10 \%, 5 \%$, and $1 \%$. The $\mathrm{z}$ value under the robust standard error of heteroscedasticity is in parentheses.

\subsubsection{Other Robustness Tests}

Replace the explained variable and use earnings per share as a substitute indicator of return on total assets to measure company performance; replace the explanatory variable, taking into account the directors' personal participation in board meetings and entrusted attendance at board meetings, and reconstruct the director's meeting attendance index. Retest the hypothesis of this article with new explanatory variables and explanatory variables, and the empirical results are similar to the above.

\section{Conclusion and Recommendations}

\subsection{Research Conclusion}

This article uses the data of Shenzhen \& Shanghai A-share listed companies from 2005 to 2019 as a sample to explore the correlation between directors' performance, remuneration and company performance. The research shows that: 1) Directors' meeting attendance is positively correlated with company performance, that is, the higher the director's meeting attendance, the better the company's performance. 2) There is no obvious correlation between whether the directors give negative opinions and the company's performance. 3) Directors' remuneration is significantly positively correlated with company performance, that is, the higher the director's remuneration, the better the company's performance. Higher director remuneration can help mobilize directors' enthusiasm for work, prompt them to perform their supervisory functions more actively, improve company governance, and thereby improve company performance.

\subsection{Research Recommendations}

Through the above analysis, this article puts forward the following countermea- 
sures and suggestions to improve director governance.

\subsubsection{Further Clarify the Role of Directors}

According to the "Company Law" of the People's Republic of China, directors are persons who have actual power and authority to manage company affairs. But from a practical point of view, in a listed company, management is responsible for management affairs. The responsibility of directors is not to engage in management, but to lead and control the company, determine the development direction of the company, and supervise the management. In practice, people often think that directors also need to manage specific company affairs, which will inevitably lead to confusion and overlap with management responsibilities, and it is not conducive to the leadership and supervision of directors.

\subsubsection{Effectively Play the Supervisory Role of Directors over Management}

In listed companies, independent directors are not the only supervisors, in fact all directors are supervisors. At present, the supervision duties of independent directors are more emphasized in listed companies, while the supervision duties of non-independent directors or internal directors are ignored.

\subsubsection{Determine the Remuneration Level of Directors According to Their Duties and Performance}

In listed companies, the regulations on the remuneration of independent directors are relatively clear, mainly determined by the remuneration committee based on the industry and the level of regional economic development. However, the regulations on the remuneration of non-independent directors or internal directors are not clear. At present, listed companies generally do not provide separate meeting allowances to non-independent directors or internal directors, and often confuse meeting allowances with annual remuneration. Therefore, it is necessary to clarify the remuneration standards of non-independent directors or internal directors, such as paying regular participation allowances for non-independent directors or internal directors on a monthly basis or the number of meetings.

\subsubsection{Improve Director Appraisal and Assessment Mechanism}

The selection and evaluation of directors shall focus on their ability to perform their duties and performance of their duties. For directors who have not performed corresponding duties and obligations, measures shall be taken to prevent them from receiving corresponding remuneration and other returns. At the same time, for directors' violation of professional ethics or laws, economic sanctions and legal consequences should be imposed. Adopt performance evaluation and appraisal system to form healthy competition among directors and encourage them to better serve the company.

\subsection{Research Limitations}

Since the degree of competition in the product market cannot be accurately measured by data, this article did not take this external governance indicator in- 
to consideration when constructing the corporate governance $\mathrm{G}$ index.

\section{Conflicts of Interest}

The authors declare no conflicts of interest regarding the publication of this paper.

\section{References}

Chakham, J. (2006). Company Evergreen: Comparison of Corporate Governance in Britain, America, France, Japan and Germany. Beijing: Renmin University of China Press.

Gao, L., Luo, Y., \& Zhang, J. (2007). The Characteristics of Independent Director System and Company Performance-An Empirical Study Based on Chinese Listed Companies. Economics and Management Research, 3, 60-66.

Han, Y. (2015). The Influence of the Characteristics of the Board of Directors on Company Performance: An Empirical Study Based on My Country's Shanghai A-Share Company. Market Modernization, 22, 110-114.

Jiang, W., Wan, H., \& Zhao, S. (2016). Reputation Concerns of Independent Directors: Evidence from Individual Director Voting. Review of Financial Studies, 29, 655-696. https://doi.org/10.1093/rfs/hhv125

Li, J. F. (2017). An Empirical Study on the Relationship between Independent Director Salary and Company Performance of State-Owned Listed Companies. Journal of Hebei University of Geosciences, 2, 87-92.

Li, W. A., \& Sun, W. (2007). An Empirical Study on the Cumulative Effect of Board Governance on Corporate Performance-Based on the Data of Chinese Listed Companies. China Industrial Economics, 12, 77-84.

Lin, J. Y., \& Jin, M. (2009). Analysis of the Correlation between the Independent Director System of Listed Companies in My Country and Company Performance. Price Monthly, $1,63-65$

Machold, S., \& Farquhar, S. (2013). Board Task Evolution: A Longitudinal Field Study in the UK. Corporate Governance: An International Review, 2, 147-164. https://doi.org/10.1111/corg.12017

Pugliese, A., Nicholson, G., \& Pietermgan, B. (2015). An Observational Analysis of the Impact of Board Dynamics and Directors' Participation on Perceived Board Effectiveness. British Journal of Management, 26, 1-25.

https://doi.org/10.1111/1467-8551.12074

Sun, J. Y. (2019). Research on the Impact of Corporate Governance on Financial Performance from the Perspective of Independent Directors' Duty Performance. Harbin: Heilongjiang University.

Trick (1997). Director. Shanghai: Foreign Languages Publishing House, Shanghai Far East Publishing House.

Wang, Q. Z., \& Bao, M. (2014). Research on the Relationship between Independent Director System and Company Performance-Based on the Data of Small and Medium-Sized Listed Companies. Finance and Accounting, 27, 28-30.

Wu, J., \& Lan, F. Q. (2009). Research on the Correlation between Independent Director System and Corporate Performance-Based on an Empirical Study of Chinese Listed Companies. Economic Forum, 14, 117-121.

Yang, Q., \& Gao, M. (2009). Director Compensation, CEO Compensation and Company Performance-Collusion or Joint Incentive? Financial Research, 6, 111-127. 
Ye, K. T., Zhu, J. G., \& Lu, Z. F. (2011). Independence of Independent Directors: Evidence Based on Board Voting. Economic Research, No. 1, 126-139.

Zhang, A. P., \& Ling, D. S. (2010). Research on the Correlation between Individual Characteristics of Independent Directors and Company Performance. Jiangxi Social Sciences, 3, 193-197.

Zhang, Q. H. (2014). Research on the Influence of Independent Directors of Listed Companies on Company Performance. Finance and Accounting Newsletter, 21, 45-48.

Zhang, S. Y. (2007). Corporate Law. Beijing: Law Press.

Zhou, F. Z., Zhou, Z., Qu, Z. T., \& Sun, K. (2010). Collusion of Interests or Supervisory Incentives: An Empirical Study Based on the Increase in the Salary of Directors and Executives of Chinese Listed Companies and Corporate Performance. 2010 (8th) Chinese Law and Economics Forum Proceedings, Volume 2, 616-629.

Zhou, J., Luo, X. Y., \& Zhang, S. P. (2016). The Formation Mechanism of Individual Effective Supervision of Independent Directors-Theoretical Construction for the Effectiveness of Board Supervision. China Industrial Economics, 5, 111-128.

Zhou, J., Wang, S. H., \& Zhang, S. P. (2018). Information Provision of Board Secretaries, Effectiveness of Independent Directors' Performance and Company Performance. Management Science, 5, 97-116. 